Is cost benefit analysis applicable to journal use in special libraries?

\title{
Is cost benefit analysis applicable to journal use in special libraries? ${ }^{\text {* }}$
}

\section{S Sridhar}

Abstract: This paper describes the concept of cost-benefit analysis in libraries, citing early uses. The need for costbenefit analysis in libraries is shown, as are difficulties in applying the technique in libraries. Although many cost minimising efforts have been made by libraries, "utility" measures were found to be intangible and inappropriate, and so a serious threat to the integrity of the cost-benefit analysis. A systematic random sample of journals subscribed by ISRO Satellite Centre Library was subjected to a simplified cost-benefit analysis. "Cost per use" of a journal appears to be useful ratio for assessing journals subscribed to by a library. The sample study of cost-benefit analysis of journals indicates that such a study does not answer all questions, but provides an additional dimension over and above what appears in a simple use study to an understanding of journal usage. The conclusion is drawn that many non-economic factors dominate the decision to subscribe to a journal. It is felt that a cost-benefit analysis can increase the awareness of librarians, administrators and others concerning costs and use patterns, but cannot be truly effective without the help of intuitive value judgment.

Keywords: Journal subscription, cost benefit analysis, journal usage, special libraries, use studies, journals budget 
Is cost benefit analysis applicable to journal use in special libraries?

\section{Introduction}

The McGraw-Hill encyclopedia of professional management defines cost-benefit analysis (CBA) as determining "... the ratio of the benefits of a given project to its cost, taking into account the benefits and costs that cannot be directly measured in dollars"1 (Bittel ed. 1978, p242) A closely related concept of cost-effectiveness analysis (CEA) "... is defined as a way of finding the least expensive means of reaching an objective or a way of obtaining the greatest possible value from a given expenditure" ${ }^{2}$ (Bittel ed. 1978, p242). Either to arrive at a benefit to cost ratio of a single project or to assess relatively the effectiveness of different projects, the identification and pertinent measure of all the costs and benefits of projects on as identical scale of measure (e.g., dollars or rupees)is necessary ${ }^{3}$.

While CBA seeks to develop standards and criteria for determining how well the existing services of a library meet the requirements of its users, CEA aims at discovering new, improved procedures and devices for providing better services to the users. CBA has been considered as a valuable tool for increasing people's awareness of the costs and benefits of information and documentation as a production factor and to provide better basis for budgeting and strategic planning.

Libraries are largely service-oriented paternalistic systems and are not susceptible to precise quantitative assessment. The cost of establishing and running a library can be estimated, but how does one measure its intangible benefits? In the past, mixed reactions have greeted the use of CBA in Librarianship in general and in dealing with journals in particular. Yet, the need for CBA in libraries has been stressed by many ${ }^{4}$ (White, 1979; Leimikuhler, 1978). Though a substantial amount of literature has been brought out on CBA, very little has been done to demonstrate the use of CBA in libraries ${ }^{5}$. 
Is cost benefit analysis applicable to journal use in special libraries?

Some attempts to apply CBA to certain areas of library works like library unionisation and networking, union catalogue, electronic security system, catalogue automation, library automation network, catalogue system, library delivery systems, manpower planning, etc., have already been made.

Wills and Oldman $^{6}$ (1977) reviewing some cost-benefit studies of libraries, question the assumption that "use" equals "value", and criticise the use of CBA for two reasons: (1) economic analysis is inappropriate where decisions have to be based on political factors (2) it is essential to explore how information supplied by libraries is used. Jenson ${ }^{7}$ (1978) also concludes that the CBA is not applicable in assessing library service. The upper hand of non-economic considerations ${ }^{8}$ (Sridhar, 1985) in decision making in libraries has been stressed by $\operatorname{Raffel}^{9}$ (1974), who says that the more critical the decision, the less useful a CBA to library decision makers.

The numerous use studies of libraries have never attempted to measure "utility" or "value" (it is almost impossible to measure precisely the utility of a document or a library) but have made certain assumptions about the operational definition of "use" of a document. Francis ${ }^{10}(1976)$ for example, finds an absence of costing standards and suggests that many problems exist in translating the statistics of book circulation into equivalent social benefits.

Apart from exploring the difficulties of applying CBA to journals, it is attempted in this paper to relate the subscription cost of a journal issue to its "use"11 during the first three months after its arrival. Kent's definition of "use" as physical selection and the act of leafing through pages of journal was adopted for the purpose. Incidentally, the "cost per use" of a journal appears to be a useful figure both in ratio 
Is cost benefit analysis applicable to journal use in special libraries?

analysis ${ }^{12}$ (Sridhar, 1986) in libraries and in ranking journals in decreasing order of cost per use.

\section{Cost-benefit analysis of journals}

Given a fixed budget, a library has to allocate its funds judiciously to various activities and services, while at the same time ensuring that it maximise benefit to cost ratio. In other words, libraries do carry out benefit-maximising and costminimising programs. For example, if the cost of maintaining an old bound journal is much higher than borrowing it from other libraries, the library may opt to weed it out. Similarly, if inhouse reprographic or micrographic work is costlier than having this work done on the outside, the library may decide to go outside for it. These are traditional make or buy decisions, and they are often, influenced by non-economic considerations.

Much has been written about cost minimising efforts in dealing with journals. Use studies, bibliometric studies, cost-benefit studies, cost-effectiveness studies, citation studies, etc., are common. All such studies have directly or indirectly attempted to rank journals subscribed to by a library (or published in a particular field) in decreasing order of productivity, "utility" or "use". In the process, assumptions are sometimes made with little attempt to isolate factors/variables that affect both the cost of the journals and the benefit they provide. A sort of straight relation between cost and benefit may be brought forth on the assumption that other factors remain constant. Such a ranked list of journals is supposed to be used, depending upon availability of funds, in making borrow or buy decisions.

Robertson and Hansman ${ }^{13}$ (1979) felt that the traditional Bradford approach to bibliographic scatter involving ranking of journals according to productivity must be modified in order to answer more directly questions concerning the costeffectiveness or cost-benefit of journal acquisition. The results obtained in using the Bradford analysis alone appeared to 
Is cost benefit analysis applicable to journal use in special libraries?

them to depend upon the particular journals that contribute to a field.

As far as cost-benefit analysis of journals is considered, Byrd and Koenig ${ }^{14}$ (1978) have pleaded for an objective cost-benefit ratio for each serial title. They point to an unfortunate situation in which selection is often based on user opinion. In addition to subscription cost, they considered many other factors in assessing values. These included coverage, impact factor, use, location, inter-library loan requests, etc. Similarly, a model for selection of journals titles based on cost-benefit ratios was developed by Kraft and Polacsek ${ }^{15}$ (1978), who analysed factors such as usage, relevance and availability of a title elsewhere.

Kent's study ${ }^{16}$ at the University of Pittsburgh was another major study in which use of books and journals was related to cost of their acquisition and maintenance (Kent et. al. 1979). But controversy arose concerning implementation of the findings of this report ${ }^{17}$ (University of Pittsburgh 1979).

\section{Methodology and sample}

In late 1983 a use study of current journals by Indian space technologists was carried out ${ }^{18}$ (Sridhar, 1986). As part of the study in-house use as well as lent out use of two latest issues of 485 current journals subscribed to by the Indian space Research Organisation (ISRO) Satellite Centre (ISAC) Library were monitored and recorded over three months from the date of their arrival and display in the library. For the purpose of applying CBA to journals, the use data of this study has been extracted in the case of about $6 \%$ of the titles. The actual sample was picked by selecting every 15th title from the list of current journals arranged alphabetically by title. Thus, this study is restricted to a sample of 33 titles. The purpose of the study was to see how effective the CBA of journals is in a special library, to 
Is cost benefit analysis applicable to journal use in special libraries?

determine how the findings of CBA of journals differ from those of a simple use study and to assess how far other factors influence the decision to retain an item or not, based on its CBA. The subscription cost of the sample journals in rupees for the year 1983 as well as their periodicity have been noted to determine cost per issue. The sample journals are analysed and compared for their cost per use.

\section{Analysis of the data}

Table 1 provides the data on 33 sample journals subscribed to by ISAC library in terms of title, periodicity, subscription cost, use and cost per use. As already mentioned, the use data in the table is extracted from an earlier use study of current journals $^{19}$ (Sridhar, 1986). The intention here is to extend the analysis done in the use study by incorporating the cost component and assessing to what extent the findings and recommendations of the use study hold good in the CBA. It is intended also to see whether or not further clues are provided by CBA in assessing the relative worth of a journal for a given library.

It may be noted from the table that the average use per issue of a journal (in the sample) during the first three months of its arrival and display in the ISAC Library is 7.5. The average subscription cost of an issue of a journal in the sample is Rs. 153.75 and the average cost per use of a single issue over the three months is Rs. 20.63 .

As the journals Energy and the Journal of Photographic Science were not used during the sample use study, their cost per use is not worked out in Table 1, and hence they are excluded from the CBA. Incidentally, these are 2 of the 60 unused journals at ISAC library recommended for cancellation in the use study. In addition, there were another 34 marginally used titles (used once or twice during the first three months of their arrival) suggested for cancellation. The sample list of journals in 
Is cost benefit analysis applicable to journal use in special libraries?

Table 1 contains three such marginally used titles: the Journal of Applied Photographic Engineering, the Journal of Engineering Physics and the Telecommunication Journal of Australia.

On the other hand, it was recommended that 28 heavily used journals (used more than 30 times during the course of the use study) be obtained by airmail subscription and/or additional copy(ies) be subscribed to. Four of them, namely, Aviation week and Space Technology, Microelectronics and Reliability, Nature and Satellite Communication occur in Table 1.

Table 2 presents the sample journals (31 titles, ignoring 2 that were unused) in increasing order of their cost per use. In addition, their respective ranks as per decreasing order of use and increasing order of cost are also indicated in the table. It is interesting to note that the rank order of these journals by cost per use and by use alone are fairly highly correlated (the Spearman Rank order correlation is 0.70 at the 0.005 significance level). This indicate that as much as 70 percent of the result of CBA is affected by the use data of journals (i.e., benefits).

An examination of Table 2 reveals that the news oriented popular journals score low in cost per use. For example, Satellite Communication received the lowest cost per use of Rs. 0.48. This is followed by Aviation week and space Technology (Rs. 0.60), Electrical Communication (Rs. 1.14), Space World (Rs. 1.15), Wireless World (Rs. 1.59), Machine Design (Rs. 1.62), Defense Electronics (Rs. 2.76), Nature (Rs. 2.85) and Control Engineering (Rs. 4.06). Of four heavily used journals (used more than 30 times), three have the lowest scores in cost per use. The journal Microelectronics and Reliability, though used heavily, scores a moderate Rs. 21.29 per use because of its relatively high subscription cost. Hence, it would not be proper to recommend airmail subscription and/or subscribing to an additional copy in its case. The journal Electrical Communication, which had a quite low use score (12), is at the 
Is cost benefit analysis applicable to journal use in special libraries?

top of the list as a result of its low cost. In other words, it has a low cost/low use profile.

On the other hand, the highest cost per use of Rs. 448.58 is scored by the Journal of Engineering Physics. Next in line are: the IEEE Proceedings B: Electrical Power Applications (Rs. 294.33), the Journal of Applied Photographic Engineering (Rs. 202.00), the Telecommunication Journal of Australia (Rs. 132.00), Solar Physics (Rs. 112.98) and the Journal of the Acoustic Society of America (Rs. 112.98). Interestingly, all three of the marginally used (used once or twice during the sample use study) titles mentioned earlier are included in the high cost per use group. In addition, another 3 journals, namely the IEEE Proceedings B: Electrical Power Applications, Solar Physics and the Journal of the Acoustic Society of America, have also become cost ineffective because of their exorbitant subscription cost. It is these high cost per use journals that should be considered for cancellation and alternative arrangements, such as the buying of Xerox copies of relevant articles, made. All six of the high cost per use (> Rs. 100.00) journals are specialised journals dealing with a specific aspect of a subject and are relatively high-priced.

\section{Conclusion}

The findings of the journal use study were put before a representative user body for a final decision on cancellation of unused and least used journals and for a decision regarding additional copies and/or airmail subscription in the case of heavily used journals. Not all of the journals recommended for cancellation were actually canceled. Nearly half were retained on the plea of subject specialists. In very few cases was the airmail/second copy arrangement approved. The cost dimension added to the use study has nevertheless substantially influenced the decision makers in cutting down the number of highly priced subscriptions. An exception occurs only in the case of a few specialised journals. 
Is cost benefit analysis applicable to journal use in special libraries?

Another factor considered was the nature of journals. For example, most of the local (Indian) journals were not only cheaper but also were demanded as a means of supporting the indigenous publishing efforts.

Two further considerations were taken into account. One had to do with whether a journal is published by a professional body or by a commercial publisher. Normally journals published by professional bodies are lower in subscription cost than are those published by commercial publishers. The second consideration dealt with whether a journal is a news/current-awareness journal meant for generalists or one that deals with a subject of interest primarily to specialists.

CBA is helpful in furthering the findings of the use study by grouping the journals of a library into four profiles, as depicted in the Figure given below.

USE

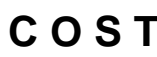

\begin{tabular}{|l|c|c|}
\hline & Low & High \\
\hline Low & 1 & 4 \\
\hline High & 2 & 3 \\
\hline
\end{tabular}

Figure: Four Profiles of Journals

Cell 1: Low cost and low use journals. A library does not mind having such journals as long as they are not creating an abnormal maintenance cost. Alternatively, as long as they are not to be kept in the library for a long time, they are desirable.

cell 2: High cost and low use journals. These need to be carefully considered for cancellation. Strong user opinion and non-economic considerations need to be given attention. 
Is cost benefit analysis applicable to journal use in special libraries?

cell 3: High cost and high use journals. These need a separate ranking to see whether or not some with a very high cost per use can be canceled and Xerox copies of needed articles acquiring and whether or not the journal can be shared with local cooperating libraries.

cell 4: Low cost and high use journals. These are the ideal journals from a CBA angle for any library.

It can be concluded that CBA may not provide a completely satisfactory solution to problems of journal retention or cancellation. It does, however, provide some clues as to how to proceed over and above those provided by a simple use study. CBA increases the awareness of librarians, administrators and users concerning collection prerogatives, but must be used in conjunction with intuitive judgment. Above all, non-economic considerations and user opinion dominate the decision making in journal subscription.

\section{REFERENCES AND NOTES}

1. Lester Robert Bittel ed, Encyclopedia of Professional Management, New York: McGraw Hill, 1978, p. 242.

2. Idem.

3. While CBA seeks to develop standards and criteria for determining how well the existing services of a library meet the requirements of its users, CEA aims at discovering new, improved procedures and devices for providing better services to the users. Vide Ferdinand F. Leimicuhler, Evaluation of Costs and Benefits of Libraries, Arlington, VA: ERIC Document Reproduction Service, 1978. ERICReport-ED-163947. (A paper presented at the Annual Conference of the Special Libraries Association, Kansas City, Missouri, June 1978).

4. As examples one may see the following. Herbert S. White, "Cost-Effectiveness and CostBenefit Determinations in Special Libraries,” Special Libraries 70 No.4 (Apr. 1979)163- 
Is cost benefit analysis applicable to journal use in special libraries?

169 and Leimakuhter, Op. cit. CBA has been considered as a valuable tool for increasing people's awareness of the costs and benefits of information and documentation as a production factor and to provide better basis for budgeting and strategic planning vide Sixton Lungberg et al. "Investigation on the Use of Information in R\&D at a Research Intensive Company, Phase II: Possibilities of Economic Evaluation,” Tidsk Dokum 32, No. 2 (1976) 17-23.

5. Some attempts to apply CBA to certain aspects of libraries like library unionisation and networking, union catalog, electronic security system, catalog automation, library automation network, catalog system, library delivery systems, manpower planning, etc., have already been made.

6. Gordon Wills and Christine Oldman, “An Examination of Cost Benefit Approaches to the Evaluation of Library and Information Services.” In: F.W. Lancaster and C.W. Cleverdon ed. Evaluation and Scientific Management of Libraries and Information Centres, Leydon, Noordhoff, 1977, p. 365-184.

7. Niels Jenson, “Cost-Benefit and the Library Service Just Don’t go Together,” Bibliotek, 70 No. 12(1978) 310-311 (In Danish).

8. As an example, one may see how the noneconomic considerations over-weighed the economic considerations in deciding standing order procurement of NASA reports. Vide M.S. Sridhar, “A Decision Theory Approach to Standing Order Procurement of NASA Reports,”Annals of Library Science and Documentation, 32 No. 2 (Mar-Jun 1985) 15-22.

9. Jeffrey A. Rafeel "From Economic to Political Analysis of Library Decision Making," College and Research Libraries, 35 No. 6 (Nov 1974) 412-423.

10. D. Pitt Francis, “Cost-Benefit Analysis and Public Library Budgets,” Library Review, 25 (1976) 189-192.

11. Kent's definition of "Use" as physical selection and the act of leafing through pages of journal was adopted. Vide Allen Kent et at, Use of Library Materials: The University of Pittsburgh Study, New York: Marcel Dekker, Inc., 1979, p. 61. 
Is cost benefit analysis applicable to journal use in special libraries?

12. M.S. Sridhar, "Ratio Analysis Technique: A Tool for Assessing the Health of a Library" In: Financial Management of Library and Information Centres; Papers Presented at XII IASLIC National Seminar 1986, Banaras Hindu University, Varanasi, 18-31 December 1986, Calcutta: 1ASLIC, 1986, pp 137-146.

13. S.E. Robertson and Sandy Hansman, "Journal Acquisition by Libraries: Scatter and CostEffectiveness,” Journal of Documentation 3! No. 4 (Dec 1979) 273-282.

14. Gary D. Byrd and Michael E.D. Koenig, "Systematic Serials Selection Analysis in a Small Academic Health Sciences Library.” Bulletin of Medical Libraries Association, 66 No. 4 (Oct 1978) 397-406.

15. Donald H. Kraft and Richard A. Polacsek, "A Journal Worth Measure for a Journal Selection Decision Model,” Collection Management, 2 No. 2 (Summer 1978) 129-139.

16. Kent et al. op. cit.

17. University of Pittsburgh, the Senate Library Committee, The Study of Library Use at Pitt by Professor Allen Kent et al: A Pittsburgh Reply. University of Pittsburgh, (Jul 1979).

18. M.S. Sridhar, "Use of Current Journals by Indian Space Technologists," The Serials Librarian 10 No. 3 (Spring 1986) 77-93.

19. Idem. 
Is cost benefit analysis applicable to journal use in special libraries?

充

TABLE

Cost per Use of Selected Journals Subscribed to by ISAC Library

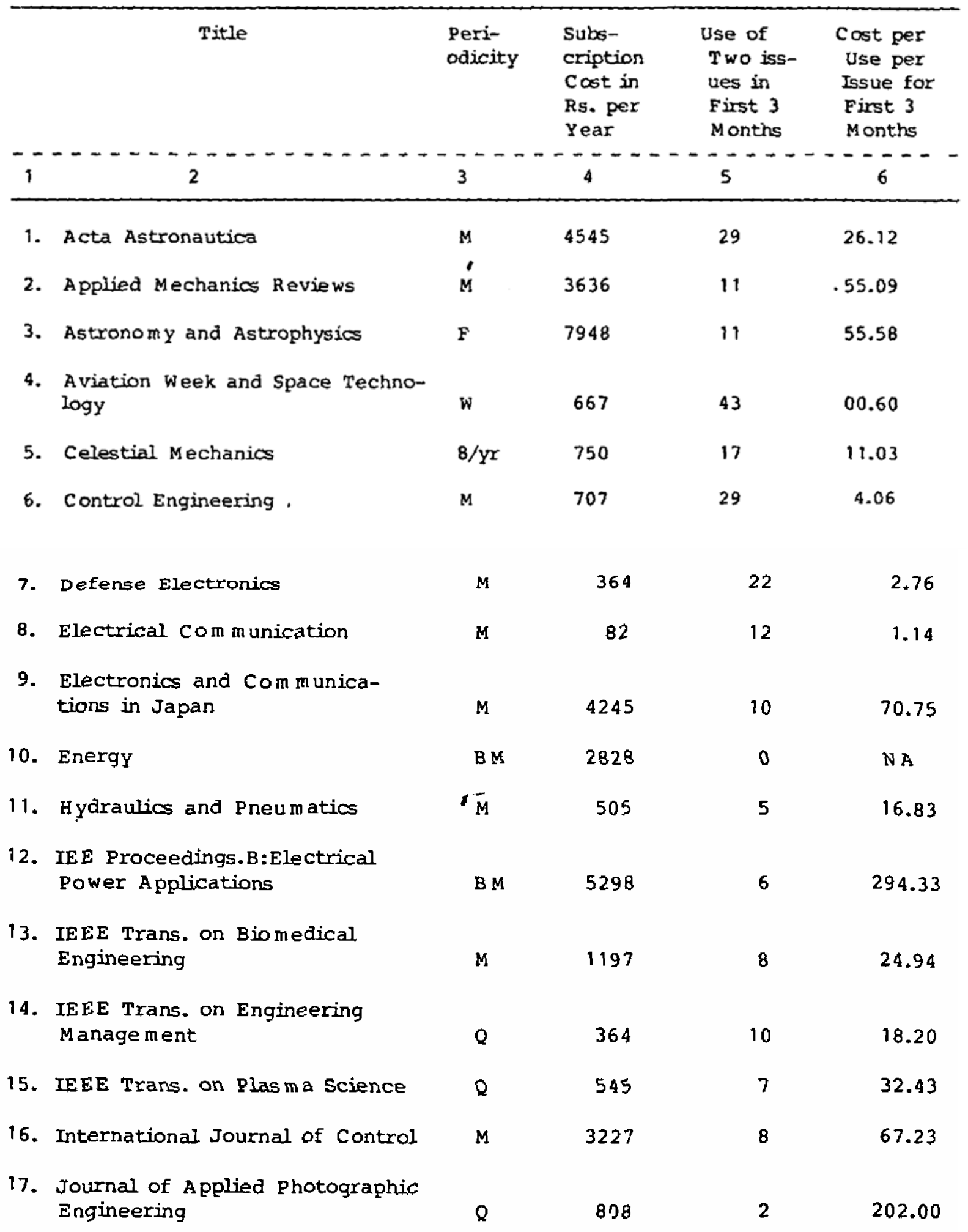


Is cost benefit analysis applicable to journal use in special libraries?

TABLE 1 (continued)

\begin{tabular}{|c|c|c|c|c|c|}
\hline 1 & 2 & 3 & 4 & 5 & 6 \\
\hline 18. & Journal of Engineering Physics & M & 5383 & 2 & 448.58 \\
\hline 19. & Journal of Photographic Science & BM & 587 & 0 & N A \\
\hline 20. & $\begin{array}{l}\text { Journal of the Acoustic Society } \\
\text { of A merica }\end{array}$ & M & 1869 & 3 & 103.83 \\
\hline 21. & $\begin{array}{l}\text { Journal of the Optical Society } \\
\text { of A merica }\end{array}$ & M & 1818 & 7 & 43.29 \\
\hline 22. & Machine Design & $\mathrm{F}$ & 505 & 24 & 1.62 \\
\hline 23. & Microelectronics and Reliability & BM & 2172 & 34 & 21.29 \\
\hline 24. & Nature & w, & 2820 & 38 & 2.85 \\
\hline 25. & Optics Com munication & M & 3648 & 13 & 46.77 \\
\hline 26. & Plating and Surface Finishing & M & 404 & 6 & 11.22 \\
\hline 27. & Radio and Electronic Engineer & M & 885 & 10 & 14.75 \\
\hline 28. & Satellite com munication & M & 151 & 52 & 0.48 \\
\hline 29. & $\begin{array}{l}\text { SIA M Journal on Control } \\
\text { and Optimisation }\end{array}$ & BM & 889 & 7 & 42.33 \\
\hline 30. & Solar Physios & $8 / y x$ & 6779 & 15 & 112.98 \\
\hline 31. & Space World & $10 / \mathrm{Yr}$ & 167 & 21 & 1.15 \\
\hline 32. & $\begin{array}{l}\text { Telecom munication Journal of } \\
\text { A ustralia }\end{array}$ & $3 / Y x$ & 198 & 1 & 132.00 \\
\hline 33. & Wireless World & $M$ & 277 & 29 & 1.59 \\
\hline
\end{tabular}

Key: NA, Not Applicable; M, Monthly; F, Fortnightly; W, Weekly; Yr, Year; $B M, B i m$ onthly; $Q, Q$ uarterly.

Note: 1. Average use per journal issue for first quarter is $\left(\frac{492}{66}=\right) 7.5$

2. Average cost of an issue of journal is Rs. $\left(-\frac{66268}{4} \frac{26}{3}\right\}=153.75$

3. The average cost per use of single issue in first quarter is Rs. $\left(\frac{2}{4} \times \frac{33}{2} \times{ }^{153.75}\right)=20.63$ 
Is cost benefit analysis applicable to journal use in special libraries?

TABLE 2

Renked List of Journgls by Cost Per Use

\begin{tabular}{|c|c|c|c|c|}
\hline $\begin{array}{l}\text { Renk } \\
\text { Order }\end{array}$ & $\begin{array}{l}\text { in- Increasin } \\
\text { of Cost Pe }\end{array}$ & Use & $\begin{array}{c}\text { Rethe in } 0 \\
\text { Drdes of }\end{array}$ & $\begin{array}{l}\text { ecreesing } \\
\text { Use }\end{array}$ \\
\hline$\imath$ & $\left\{\int_{i, 4}^{0,48}\right\}$ & Setellite Communicetion & 3 & $(52)$ \\
\hline 2 & $(0.60)$ & Avietion Week end Spece Technology & 2 & $(43)$ \\
\hline 3 & $(0.14)$ & Electricel Communicetion & 34 & $(12)$ \\
\hline 4 & $(1.15)$ & Spece World & 10 & $(2 \imath)$ \\
\hline 5 & $(1.59)$ & Wireless World & 6 & $(29)$ \\
\hline 6 & $(1.62)$ & Mechine Design & 8 & $(24)$ \\
\hline 7 & $(2.76)$ & Defense Electronics & 9 & $(22)$ \\
\hline B & $(2.85)$ & Neture & 3 & (38) \\
\hline 9 & $(4.06)$ & Control Engineering & 6 & (29) \\
\hline 10 & $(11.03)$ & Celestial Mechenics & 11 & $(17)$ \\
\hline 11 & $(11.22)$ & Pleting end Surfece Finishing & 25.5 & $(6)$ \\
\hline 12 & $(14.75)$ & Redlo and Electronic Engineer & 18 & $(10)$ \\
\hline 13 & $(16.83)$ & Hydreulics end Pneumetics & 27 & $(5)$ \\
\hline 14 & $(18.20)$ & IEEE Trens, on Engineering Mpnegement & 18 & $(10)$ \\
\hline 15 & $(21.29)$ & Microelectronics end Reliebility & 4 & $(34)$ \\
\hline 16 & $(24.94)$ & IEEE Trens. on Biamedicel Engineering & 20.5 & $(8)$ \\
\hline 17 & $(26.12)$ & Acte Astroneutice & 6 & $(29)$ \\
\hline 18 & $(32.43)$ & IEEE Trens. on Plesme Science & 23 & $(7)$ \\
\hline 19 & $(42.33)$ & SIAM Journal Control end Optimisetion & 23 & $(7)$ \\
\hline 20 & $(42.29)$ & Journel of the Opticel Society of Americe & 23 & ( 7$)$ \\
\hline 21 & $(46.77)$ & Optics Communicetion & 13 & $(13)$ \\
\hline 22 & $(55.09)$ & Applied Mechenics Review & 15.5 & $(11)$ \\
\hline 23 & $(55.58)$ & Astronomy end Astrophysics & 15.5 & $(11)$ \\
\hline 24 & $(67.23)$ & Internetionel Journel of Control & 20.5 & ( 8$)$ \\
\hline 25 & $(70.75)$ & Electronics end Communicetion in Jepen & 18 & $\{10\}$ \\
\hline 26 & $(103.83)$ & Joutnel of the Acoustic Society of Ametice & 28 & ( 3$)$ \\
\hline 27 & $(112.98)$ & Soler Physics & 12 & (15) \\
\hline
\end{tabular}


Is cost benefit analysis applicable to journal use in special libraries?

TABLE 2 (continued)

\begin{tabular}{|c|c|c|c|c|}
\hline \multicolumn{3}{|c|}{$\begin{array}{l}\text { Renk In Increesing } \\
\text { Order of Cost Per Use }\end{array}$} & \multicolumn{2}{|c|}{$\begin{array}{l}\text { Renk in Decrepsing } \\
\text { Order of Use }\end{array}$} \\
\hline 28 & $(132.00\rangle$ & Telecommunicetion Journel of Austrelle & 31 & (1) \\
\hline 29 & $(202.00)$ & Journel of Applled Photogrephic Engineering & 29.5 & ( 2$)$ \\
\hline 30 & $(294.33)$ & $\begin{array}{l}\text { IEE Proceedings B:Electricel Power Appli- } \\
\text { cetions }\end{array}$ & 25.5 & ( 6$)$ \\
\hline 31 & $(448.58)$ & Jousnel of Engineering Phystes & 29.5 & $(2)$ \\
\hline
\end{tabular}

Note: The Speermen ${ }^{R}$ enk Order Corseletion between two tenkings is

$r_{s}=1-\frac{6 \times D I^{2}}{n\left(n^{2}-1\right)}=0.7068$. The t-test value besed on

$t=r_{s} \sqrt{\frac{\pi-2}{1-t_{s}}}$ is $5.3805 .8 y$ looking oft the tabulated value of

$t$, it is found that correlation is satistically significant at 0.005 .

The Serials Librarian 15 (1/2) 1988: 137-153.

\section{About the Author}

Dr. M. S. Sridhar is a post graduate in Mathematics and Business Management and a Doctorate in Library and Information Science. He is in the profession for last 36 years. Since 1978, he is heading the Library and Documentation Division of ISRO Satellite Centre,

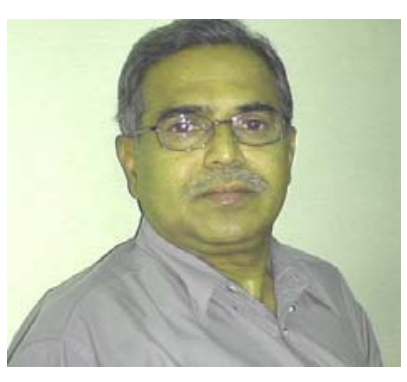
Bangalore. Earlier he has worked in the libraries of National Aeronautical Laboratory (Bangalore), Indian Institute of Management (Bangalore) and University of Mysore. Dr. Sridhar has published 4 books, 83 research articles, 22 conferences papers, written 19 course materials for BLIS and MLIS, made over 25 seminar presentations and contributed 5 chapters to books. E-mail:sridharmirle@yahoo.com, mirlesridhar@gmail.com, sridhar@isac.gov.in ; Phone:91-80-25084451; Fax: 91-80-25084476. 